\title{
DISTRIBUTION AND POSTBREEDING ENVIRONMENTAL RELATIONSHIPS OF NORTHERN LEOPARD FROGS (RANA [LITHOBATES] PIPIENS) IN WASHINGTON
}

\author{
Stephen S. Germaine ${ }^{1,3}$ and Dave W. Hays ${ }^{2}$
}

\begin{abstract}
Northern leopard frogs (Rana [Lithobates] pipiens) are considered sensitive, threatened, or endangered in all western states and western Canadian provinces. Historically present in eastern Washington in 6 major river drainages, leopard frogs are now only known to occur at 2 localized areas in the Crab Creek drainage in Grant County. During the summers of 2002-2005, we surveyed both areas to document extent of leopard frog distributions and to describe habitat and vertebrate community characteristics associated with leopard frog site occupancy. At Gloyd Seeps, 2 juvenile leopard frogs were observed in a total of 8.2 person-days of searching along a 5-km stream reach. At Potholes Reservoir, we surveyed 243 wetland sites in 7 management units known to have been occupied by leopard frogs during the 1980s. We confirmed leopard frog presence at only 87 sites (36\%) in 4 management units. Site occupancy models for individual ponds indicated that, compared to unoccupied sites, occupied sites had slightly greater pond depths, less tall emergent vegetation, more herbaceous vegetative cover, and fewer neighboring ponds containing nonnative predatory fish. Models developed at the $1-\mathrm{km}^{2}$ scale indicated that occupied areas had greater average midsummer pond depths, fewer ponds occupied by bullfrogs (Rana [Lithobates] catesbeiana) and carp (Cyprinus carpio), and more herbaceous vegetation surrounding ponds. The Gloyd Seeps population now appears defunct, and the Potholes Reservoir population is in sharp decline. Unless management actions are taken to reduce nonnative fish and bullfrogs and to enhance wetland vegetation, leopard frogs may soon be extirpated from both sites and possibly, therefore, from Washington.
\end{abstract}

Key words: northern leopard frog, Rana (Lithobates) pipiens, nonnative fish, bullfrog, Rana catesbeiana, population declines, predation, site occupancy, wetland vegetation, Washington.

Despite widespread geographic distribution in North America, the northern leopard frog (Rana [Lithobates] pipiens; hereafter leopard frog) is now considered a sensitive, threatened, or endangered species in all western states and western Canadian provinces (see Alberta Wildlife Act 1996, Washington Fish and Wildlife Commission 2000, Conservation Data Centre of British Columbia 2001, COSEWIC 2002) and has been petitioned for listing as a federal candidate species (Anonymous 2006). In Washington, leopard frogs were elevated to endangered status after surveys of the 17 known historic locations confirmed occupancy at only 2 sites (Leonard et al. 1999). Historically present in the Columbia, Crab Creek, Pend Oreille, Snake, Spokane, and Walla Walla river drainages, leopard frogs are now only known in Washington at the Gloyd Seeps and Potholes Reservoir areas of the Crab Creek drainage in Grant County.

Leopard frogs disappeared from most sites in Washington by the mid-1980s (Leonard et al. 1999), and timing of declines was similar in neighboring states and provinces. In Alberta, leopard frog populations declined during the late 1970s and have not recovered (Kendell 2003), and only one known population remains in British Columbia (Adama et al. 2004). In the northwestern United States, leopard frogs may have been extirpated from Oregon (St. John 1985, Stebbins 2003), and populations have declined in Idaho and Nevada (Groves and Peterson 1992, Panik and Barrett 1994, Koch et al. 1997).

Primary putative factors affecting leopard frogs include disease, habitat fragmentation and loss, artificial hydrologic manipulation, aquatic contaminants, bullfrogs (Rana [Lithobates] catesbeiana), and nonnative fish (Hayes and Jennings 1986, Hecnar and M'Closkey 1997a, Kendell 2003). In western North America, multiple factors appear responsible (Corn 1994), with habitat alteration and exotic species introductions considered the greatest threats (Richter et al. 1997). However, none of these

${ }^{1}$ Science Division, Washington Department of Fish and Wildlife, Olympia, WA 98501.

${ }^{2}$ Diversity Division, Washington Department of Fish and Wildlife, Olympia, WA 98501.

3Present address: USGS Fort Collins Science Center, Fort Collins, CO 80526. E-mail: germaines@usgs.gov 
studies were conducted in Washington. Our objectives were therefore to document the distribution of northern leopard frogs at the Gloyd Seeps and Potholes Reservoir areas and relate site occupancy to local vegetative, hydrologic, and nonnative-predator characteristics.

\section{Methods \\ Study Area}

Gloyd Seeps (GS) and Potholes Reservoir (PR) lie $24 \mathrm{~km}$ apart along Crab Creek, Grant County, Washington, with Moses Lake Reservoir and its namesake town located between them. Both sites are on land administered by the Washington Department of Fish and Wildlife (WDFW), which administers Potholes Reservoir Unit jointly with the USDI Bureau of Reclamation (BOR). The BOR manages Potholes Reservoir as an agricultural water source under Columbia Basin Project (USDI-BOR 2002) directives. The mandate to provide irrigation constrains managers' ability to manipulate water levels to benefit native amphibians such as leopard frogs.

Wetlands at GS consisted of about 10 linear $\mathrm{km}$ along Crab Creek containing several small (<1-km-long) impoundments. Wetland vegetation was primarily low emergent and moisture-tolerant herbaceous species growing sporadically in narrow $(2-10-\mathrm{m})$ linear bands along the creek. Lentic, shallow areas containing emergent vegetation that might serve as potential breeding sites were present but rare.

Wetlands at PR included an 8.8-km reach of Crab Creek and several hundred small ponds ranging in size from $<0.1$ to 30 ha surface area. Wetland vegetation at both areas included emergent (Carex, Eleocharis, Juncus, Scirpus, Schoenoplectus, and Typha spp.), grass-forb (Polygonum, Bidens, and Xanthium spp. and Lactuca serriola), and willow (Salix spp.) vegetation in both shrub and tree form. Reed canarygrass (Phalaris arundinacea), common reed (Phragmites sp.), and purple loosestrife (Lythrum salicaria) were rare but present.

At PR we surveyed ponds in 7 hydrologically distinct management units (USDI-BOR 2002), each of which had at least one record of a post-1980 leopard frog sighting (Leonard et al. 1999, McAllister et al. 1999, WDFW Heritage Database 2005). Units surveyed included Dunes, Lower Crab Creek, North Potholes Reserve, Peninsula North, Peninsula South,
Upper Crab Creek, and Upper West Arm. At PR in 2002, we focused surveys on areas most recently occupied by leopard frogs and on adjacent wetlands. During 2003-2004, we overlaid random sampling points on digital aerial photographs that were spatially rectified and high resolution, and we surveyed the wetland nearest each point. Because wetlands at GS were primarily linearly oriented along Crab Creek, we searched all of them, especially focusing on areas where leopard frogs had been observed since 1995 and on areas of suitablelooking habitat based on published descriptions (Dole 1965, Hine et al. 1981, Kendell 2002).

Leopard frog egg-laying occurs in late April to early May in our area (S. Germaine personal observation). This period coincided with annual rapid water impoundment at $\mathrm{PR}$, and water levels rose $\geq 1 \mathrm{~m}$ during the period of egg-mass deposition and early larval development. During this time, most ponds surface-connected to large fish-bearing water bodies, and water levels rose into upland vegetation. During 1995-2004, annual high-water levels at PR occurred between 12 March and 15 June. Drawdown began immediately, and water levels had dropped 3-4 $\mathrm{m}$ by the time of larval metamorphosis, which occurred in mid-July in our area. Annual low-water levels occurred between 2 September and 23 October. During low water, mud and sand flats were exposed, and many shallow ponds dried completely.

Carp (Cyprinus carpio), rainbow trout (Oncorhynchus mykiss), brown trout (Salmo trutta), brown bullhead (Ameiurus nebulosus), walleye (Stizostedion vitreum), and bluegill (Lepomis macrochirus) were present in both areas. Largemouth bass (Micropterus salmoides), smallmouth bass (Micropterus dolomieui), pumpkinseed (Lepomis gibbosus), black and white crappie (Pomoxis nigromaculatus and Pomoxis annularis), and yellow perch (Perca flavescens) were also present at PR (Washington Department of Fish and Wildlife unpublished data). In addition, mosquitofish (Gambusia affinis) were present in at least 2 isolated ponds in this area. None of these species are locally native.

\section{Sampling}

To determine leopard frog occupancy at each wetland, we conducted time-constrained visual-encounter surveys (Crump and Scott 1994, Olson et al. 1997, Kendell 2002) at both areas from July through early October of 
2002-2005 (2002-2004 at PR, 2003-2005 at GS). During these months, juvenile leopard frogs were easy to observe (Kendell 2002, Simmons 2002), and bullfrogs were easily detectable via calling activity into early August, with bullfrog larvae and juveniles visibly detectable through September. We surveyed during daytime by slowly walking along waterlines and concentrating primarily on floating vegetative mats, shallow water with low emergent vegetation, and terrestrial areas of low emergent or herb/forb vegetation on moist to saturated soils. During summer, these areas were frequently used by leopard frogs (Dole 1965). Leopard frogs were seldom found in high $(\geq 1 \mathrm{~m})$ grassy vegetation (Merrell 1977), and Merriam (2002) observed leopard frogs $87 \%$ of the time in microsites having no overstory vegetation Hine et al. 1981). We therefore searched less-optimal areas (e.g., tall emergent vegetation) only after searching in focal habitat types and as time permitted. During searches, we methodically swept longhandled nets through vegetation to increase the likelihood of flushing frogs. At large ponds and sites permanently connected to the creek or reservoir, we surveyed 200-300 m of shoreline adjacent to the random-point origin. Time spent actively surveying at each site was generally 20-45 person-minutes, with variation among sites due to variation in wetland size; each wetland was searched at a uniform rate.

We also noted presence of bullfrogs and visually searched through the water column for fish from multiple vantage points around each pond. When we observed fish, we identified them to the most precise taxonomic level possible. In addition, we noted whether focal ponds connected at least seasonally to permanent water bodies (e.g., Crab Creek, Potholes Reservoir, or a large reservoir in the North Potholes Reserve), all of which contained nonnative predatory fish and bullfrogs. We also noted whether focal ponds were ephemeral or permanent and whether they connected annually to other permanent ponds. We estimated maximum pond depth by noting high-water marks on shoreline vegetation. We measured actual pond depths by wading to pond center, and we indexed water clarity by inserting a white, 2.54-cm-diameter pole $0.5 \mathrm{~m}$ into each pond. Index values were clear (visibility $>50$ $\mathrm{cm}$ ), tannin colored (white pole became tea colored), slightly murky (visibility $20-50 \mathrm{~cm}$ along pole), or murky (visibility $<20 \mathrm{~cm}$ ). In cases where water depth was $<0.5 \mathrm{~m}$, observers classified ponds as clear if objects on the bottom could be seen with fine detail, slightly murky if the bottom could be seen but with poor detail, and murky if the bottom could not be seen. Aided by high-resolution aerial photography, we walked pond perimeters and visually estimated percent vegetative cover to the nearest $5 \%$ in the following classes: tall emergent, low emergent, herbaceous, woody scrub-shrub, submerged or floating aquatic vegetation, and open water-exposed mudflats. All wetlandassociated vegetation occurring below the ecotone with upland shrubsteppe vegetation was included in estimates.

\section{Analyses}

We related leopard frog site occupancy to environmental attributes by contrasting vegetative, vertebrate, and hydrologic characteristics of individual ponds using binary logistic regression and an information-theoretic multimodel comparison approach (Burnham and Anderson 2002). This calculation was done at 2 spatial scales: in individual ponds and in 1$\mathrm{km}^{2}$ areas within which individual pond data had been pooled. We chose a $1-\mathrm{km}^{2}$ spatial scale because juvenile leopard frogs may disperse up to $1 \mathrm{~km}$ soon after metamorphosis (Dole 1971, Seburn et al. 1997) and because radio-telemetered adult leopard frogs traveled this distance while migrating from breeding ponds to overwintering ponds in a related study (S. Germaine unpublished data). This scale also facilitated a logical organizational unit in GIS.

Because our survey season encompassed the period of rapid juvenile dispersal, we considered it likely that dispersing juvenile frogs would occasionally be encountered at ponds poorly suited to them. To reduce analytical noise associated with these observations, when developing models at the pond scale, we adjusted our logistic cutpoint to less than or $\geq 1$ frog observed per 15 minutes of survey effort, following pseudospecies methods described by Hill et al. (1975) and Jongman et al. (1995). When developing models at the $1-\mathrm{km}^{2}$ scale, we used true presence (observed)-absence (not observed) to model wetland characteristics of grid cells.

Candidate predictor variables in the logistic regression model included the vegetative and hydrologic variables described above, plus 
an enumeration of the neighboring ponds containing bullfrogs, carp, and predatory fish. We generated this number by counting how many of the 6 nearest neighboring ponds (inclusive of focal ponds) contained each type of nonnative vertebrate. We required ponds to be $\leq 1$ $\mathrm{km}$ from focal ponds but made no further effort to account for variability in distance between ponds. Within 1-km² cells, we generated average and maximum values for each candidate predictor variable.

At each spatial scale, we evaluated the following competing models: a full global model, 1-2 reduced global models, a hydrologic-vegetative model, a hydrologic-nonnative vertebrate model, a vegetative-nonnative vertebrate model, a hydrologic model, a vegetative model, and a nonnative vertebrate model. The pond-scale full global model contained the variables pond depth, tall emergent vegetative cover, open water-exposed mud, herbaceous vegetative cover, bullfrog abundance, and fish abundance; the $1-\mathrm{km}^{2}$-scale global model contained the variables pond depth, water clarity, maximum observed tall emergent vegetative cover, maximum observed herbaceous vegetative cover, bullfrog abundance, and carp abundance. While each independent variable in our study was chosen based on a priori information about its potential to influence leopard frog distributions, we screened each variable prior to model development by requiring $t$ scores $\geq 0.7$ when grouped on the dependent variable. We assessed correlations between candidates; and in all pairwise instances of $r \geq 0.60$, we retained only the variable thought to be of greater importance, based on other studies. For each model other than the full global model, we assessed within-model combinations of variables for confounding and interaction and kept only subsets of variables that fit the data as well as each initial model did based on log-likelihood $\mathrm{G}$ scores at $\alpha=0.05$ (Hosmer and Lemeshow 1989).

We used the second-order Akaike's information criterion $\left(\mathrm{AIC}_{c}\right)$ values to compare models within each spatial scale because $\mathrm{AIC}_{c}$ is adjusted for small sample sizes (Burnham and Anderson 2002). Low $\mathrm{AIC}_{c}$ scores indicated models that used relatively few variables to achieve high fit to the data relative to other models being assessed. We ranked models by calculating Akaike weighted probabilities $\left(w_{i}\right)$ for each score. Akaike weights rank models from best (high scores) to poorest using an objective proportional ranking factor that sums to 1 over all models (Burnham and Anderson 2002). Once optimal models were identified at each spatial scale, we reran our logistic regression analyses and generated prediction-success tables to determine the classificatory success of each model using SYSTAT software (SYSTAT 2004).

\section{REsults}

At GS in 2003, we observed 2 juvenile leopard frogs in 0.5 person-days while searching a 0.5-km length of Crab Creek. In 2004 and 2005, we surveyed approximately $9.1 \mathrm{~km}$ along the creek in 7.7 person-days and confirmed no leopard frogs. In 2004, one suspect leopard frog exhibiting long zigzag jumps (Stebbins 2003) was observed but not captured for verification.

At PR we surveyed 243 individual wetland ponds within a $41-\mathrm{km}^{2}$ area in the 7 management units during 2002-2004. Fifty-five ponds (23\%) were surveyed in multiple years, resulting in a total of 302 surveys. For ponds surveyed multiple times, we kept only the information from the survey with the highest abundance of leopard frogs. Leopard frogs were present at 87 PR ponds.

Because of the paucity $(n=2)$ of leopard frogs at GS, we collected detailed habitat data and modeled environmental relationships only at PR. At PR, distribution of leopard frogs and nonnative vertebrates varied among management units, as did the number of seasonally surface-connected ponds. Percent pond occupancy by leopard frogs was highest in the Upper Crab, Lower Crab, and Peninsula North management units, and leopard frogs were rare or absent elsewhere. Bullfrogs were largely absent from Upper Crab, Lower Crab, and Peninsula North but were present in $>25 \%$ of all ponds surveyed in each management unit in the west half of the study area and in $>60 \%$ of ponds in the Dunes and Upper West Arm units. Carp and nonnative sportfish were abundant in all units except Peninsula North, where they were entirely absent. More than $75 \%$ of ponds in all management units except for the Upper Crab and Peninsula North units contained multiple nonnative vertebrate types.

We collected environmental data at 222 surveyed sites throughout PR, and 8 variables met criteria for inclusion in pond-specific model building: surface connectivity, pond depth (at 
TABLE 1. Akaike's information criteria parameters and log-likelihood scores for 8 logistic regression models characterizing environmental factors associated with leopard frog pond occupancy at Potholes Reservoir Wildlife Area, WA, 2002-2004. Best models, based on differences in weighted AIC values, shown in boldface. Variable definitions: PD = pond depth (at time of survey); CONNECT $=$ degree of pond isolation; $\mathrm{TE}=$ tall emergent vegetative cover; OWEX $=$ open water or exposed mudflat containing $\leq 10 \%$ vegetative cover at water or soil surface; $\mathrm{HE}=$ live herbaceous vegetation; $\mathrm{BFab}=$ bullfrog abundance; $\mathrm{Fab}=$ nonnative predatory fish abundance.

\begin{tabular}{|c|c|c|c|c|c|}
\hline Model: \pm coefficients(variables) & $K$ & $\log _{\mathrm{e}}(\mathrm{L})$ & AIC & $\Delta \mathrm{AIC}_{c}$ & $w_{i}$ \\
\hline Global reduced: $0.68(\mathrm{PD})-0.04(\mathrm{TE})+0.02(\mathrm{HE})-0.27(\mathrm{Fab})$ & 6 & -55.29 & 123.13 & 0.00 & 0.68 \\
\hline $\begin{array}{l}\text { Global: } 0.69(\mathrm{PD})-0.04(\mathrm{TE})+0.00(\mathrm{OWEX})+0.01(\mathrm{HE})- \\
\quad 0.27(\mathrm{BFab})-0.26(\mathrm{Fab})\end{array}$ & 7 & -54.49 & 125.94 & 2.81 & 0.17 \\
\hline Hydro + Veg reduced: $0.41(\mathrm{PD})-0.03(\mathrm{TE})+0.02(\mathrm{HE})$ & 4 & -58.13 & 126.64 & 3.51 & 0.12 \\
\hline Hydro + Exotics reduced: 0.62(PD) $-0.26(\mathrm{Fab})$ & 3 & -60.44 & 129.13 & 6.00 & 0.03 \\
\hline Hydrology: 0.43(CONNECT $)+0.58(\mathrm{PD})$ & 3 & -62.97 & 134.19 & 11.06 & 0.00 \\
\hline Veg + Exotics reduced: $-0.03(\mathrm{TE})-0.29(\mathrm{Fab})$ & 3 & -67.04 & 142.32 & 19.18 & 0.00 \\
\hline Veg reduced: $0.02(\mathrm{HE})$ & 2 & -69.31 & 144.76 & 21.62 & 0.00 \\
\hline Exotic Vertebrates reduced: $-0.23(\mathrm{Fab})$ & 2 & -71.10 & 148.33 & 25.20 & 0.00 \\
\hline
\end{tabular}

TABLE 2. Akaike's information criteria parameters and log-likelihood scores for 5 logistic regression models characterizing environmental factors associated with leopard frog occupancy of $1-\mathrm{km}^{2}$ wetland areas at Potholes Reservoir Wildlife Area, WA, 2002-2004. Best model, based on both differences in AIC scores and weighted AIC, shown in boldface. Variable definitions: pond depth $=$ average pond depth; clarity $=$ average water clarity; $\operatorname{maxTE}=$ maximum value of tall emergent vegetative cover; maxHE = maximum value of live herbaceous vegetation; $\mathrm{BFab}=$ average bullfrog abundance; $\mathrm{CAab}=$ average carp abundance.

\begin{tabular}{|c|c|c|c|c|c|}
\hline Model: \pm coefficients (variables) & K & $\log _{\mathrm{e}}(\mathrm{L})$ & AIC & $\Delta \mathrm{AIC}_{c}$ & $w_{i}$ \\
\hline $\begin{array}{l}\text { Global reduced: } 3.47 \text { (pond depth })+0.02(\text { maxHE })- \\
0.84(\text { BFab })-0.35(\text { CAab })\end{array}$ & 6 & -18.49 & 52.19 & 0.00 & 0.76 \\
\hline $\begin{array}{l}\text { Global: } 2.35(\text { pond depth })+0.45(\text { clarity })-0.01(\text { maxTE })+ \\
\quad 0.02(\text { maxHE })-0.71(B F a b)-0.44(\text { CAab })\end{array}$ & 8 & -17.36 & 55.36 & 3.17 & 0.16 \\
\hline Nonnative Vertebrates: $-0.68(\mathrm{BFab})-0.17(\mathrm{CAab})$ & 4 & -23.95 & 56.96 & 4.77 & 0.07 \\
\hline Hydrology: 0.54(pond depth) +0.29 (clarity) & 4 & -26.95 & 63.04 & 10.85 & 0.00 \\
\hline Vegetation: $0.02(\operatorname{maxTE})+0.02(\operatorname{maxHE})$ & 4 & -26.04 & 61.13 & 8.94 & 0.01 \\
\hline
\end{tabular}

time of survey), percent area covered by tall emergent, herbaceous, or woody-stemmed vegetative types, percent area of open waterexposed mudflat, abundance of bullfrogs, and abundance of predatory fish. Variables for woody-stemmed and herbaceous vegetation were highly correlated (Pearson $r=-0.97$ ). We considered herbaceous vegetation more important to leopard frogs (Dole 1965, Merrell 1977, Hine et al. 1981) and therefore removed woodystemmed vegetation from further analysis. Surface connectivity and predatory fish abundance were also correlated (Pearson $r=0.64$ ), so we excluded connectivity from all models containing both hydrologic and nonnative vertebrate variables. We didn't find any interaction terms that improved model fit to the data.

Based on the $w_{i}$ values, greater empirical support existed for the reduced global model than for any other model evaluated (Table 1; Burnham and Anderson 2002). The reduced global model was significant $\left(\chi^{2}=17.25, \mathrm{df}=\right.$
$4, P=0.002)$ and correctly classified $87.7 \%$ of occupied sites but had poor success $(23.4 \%)$ in classifying sites where few or no frogs occurred.

Based on the variables in the reduced global model, sites containing leopard frogs during the postbreeding summer season had the following characteristics (Fig. 1): greater pond depths (median $0.5 \mathrm{~m}$; interquartile range $0.1-1.0 \mathrm{~m}$ ), less tall emergent vegetative cover (median 10\%; 10\%-20\%), more herbaceous vegetative cover (median 80\%; 30\%-90\%), and few fish (median index value 1; 0-4 neighboring pond[s] containing nonnative fish).

Six variables met criteria for inclusion in model-building at the $1-\mathrm{km}^{2}$ scale: average pond depth, water clarity, maximum percent cover of tall emergent and herbaceous vegetation, and abundances of bullfrogs and carp. Again, no interaction terms improved the model's fit to the data. Weighted AIC $\left(w_{i}\right)$ values indicated overwhelming support for the reduced global model (Table 2). 
a

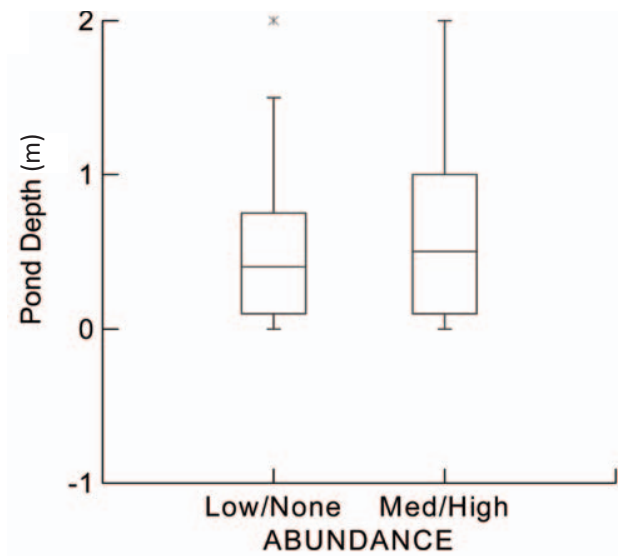

C

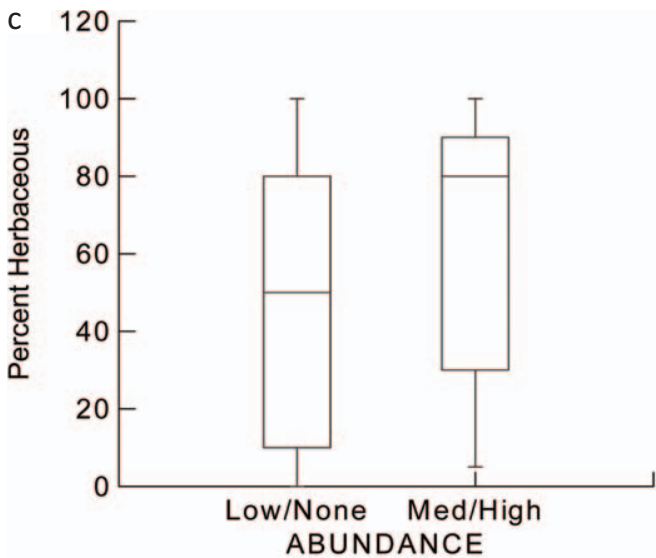

b

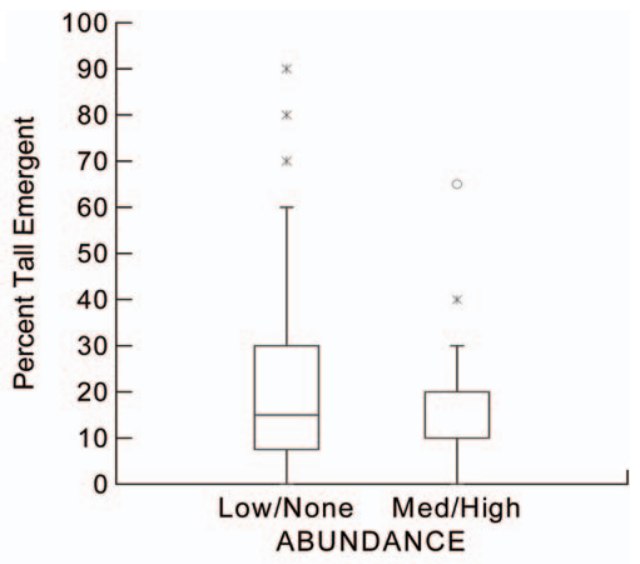

d

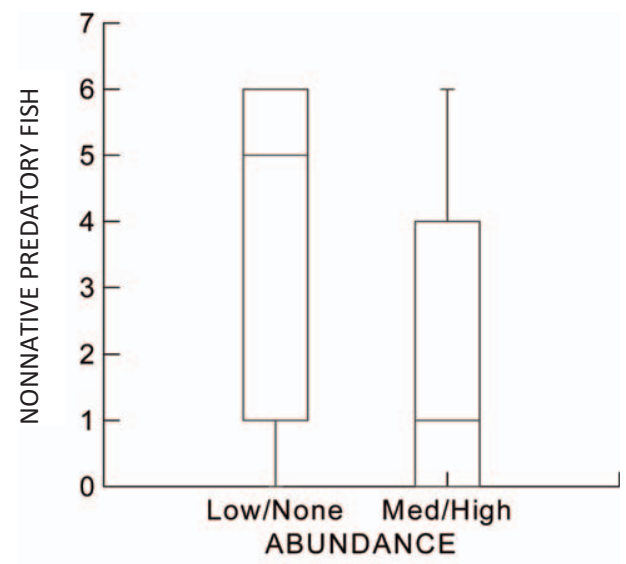

Fig. 1. Median values and 25th and 75th percentile values (box ends) for variables included in the most parsimonious of 5 models evaluated for ability to classify ponds by leopard frog abundance in Potholes Reservoir Wildlife Area, Washington, 2002-2004. Panels depict (a) pond depth (m), (b) percent area composed of tall emergent vegetation, (c) percent area covered in herbaceous vegetation, and (d) number of neighboring ponds (range 0-6) containing nonnative predatory fish. Asterisks $\left(^{*}\right)$ represent outlier values lying beyond $1.5 \times$ hinge-spread range.

The reduced global model for the $1-\mathrm{km}^{2}$ scale was significant $\left(\chi^{2}=21.14, \mathrm{df}=4, P<\right.$ 0.001 ), and correctly classified $72.5 \%$ of occupied areas and $69.8 \%$ of unoccupied areas. Areas occupied by leopard frogs during the postbreeding summer season had deeper average water depths, greater maximum amounts of herbaceous vegetative cover, and fewer ponds occupied by bullfrogs and carp than did areas where we found no leopard frogs (Fig. 2).

\section{Discussion}

Leopard frog populations have clear trends and associations with nonnative vertebrates in our study area. We found leopard frog distributions at both GS and PR severely reduced rela- tive to 10-20 years ago. At GS we documented no reproduction and observed only 2 leopard frogs during 3 years of surveying. The PR population now appears to be present in only 4 (57\%) of the 7 management units in which it occurred during the 1980s. In 1 of the 4 PR units still occupied (the North Potholes Reserve Unit), leopard frogs were present at only $7 \%$ of the sites surveyed and co-occurred in all instances with both bullfrogs and nonnative fish.

At both spatial scales, strong empirical support existed for models containing vegetative, nonnative vertebrate, and hydrologic variables, suggesting that a suite of environmental factors influenced leopard frog distributions during summer. Also, our logistic regression models demonstrated that leopard frogs were 

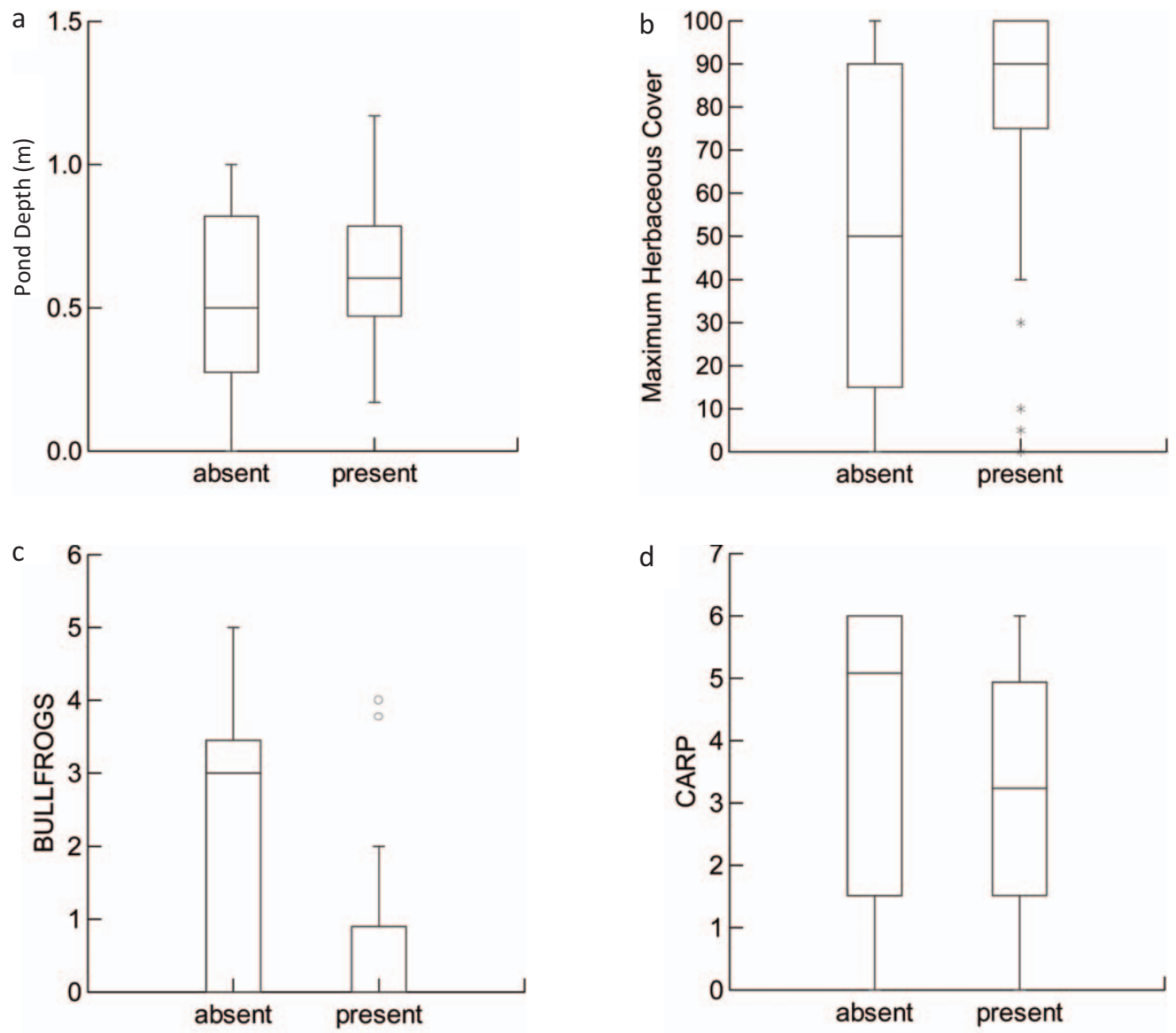

Fig. 2. Median values and 25th and 75th percentile values (box ends) for variables included in the most parsimonious of 5 models evaluated for ability to classify $1-\mathrm{km}^{2}$ wetland areas by leopard frog presence/absence in Potholes Reservoir Wildlife Area, Washington, 2002-2004. Panels depict (a) average pond depth (m), (b) maximum value of herbaceous vegetative cover, (c) average number of ponds occupied by bullfrogs, and (d) average number of ponds containing carp. Asterisks $(*)$ represent outlier values lying beyond $1.5 \times$ hinge-spread range. Circles $(0)$ represent outlier values lying beyond $3 \times$ hinge-spread range.

negatively associated with both bullfrogs and nonnative predatory fish.

While correlative studies do not prove cause and effect, a large body of published literature exists associating nonnative sportfish and bullfrogs with declines in native amphibian populations. Fish prey upon all life stages of ranid frogs, and heterogeneous fish assemblages are capable of causing local extinctions and altering distribution patterns (Petranka 1983, Hayes and Jennings 1986, Hecnar and M'Closkey 1997a, Bradford et al. 1993). Hine et al. (1981) concluded that fish predation could substantially reduce a leopard frog population, and multiple studies have described optimal leopard frog breeding ponds as free of nonnative fish
(Hine et al. 1981, Knutson et al. 2004). Most introduced fish species in the Pacific Northwest are aggressive and efficient generalist predators with whom native amphibians are not well adapted to coexist (Kats et al. 1988, Werner and McPeek 1994, Skelly 1996). Monello and Wright (1999) found a variety of amphibians absent from ponds containing introduced fish, with only the bullfrog able to reproduce successfully in fish-bearing ponds.

Bullfrogs also have a strong influence on amphibian community structure (Hecnar and M'Closkey 1997b, Laufer et al. 2007). Bullfrog colonization of the Upper West Arm and North Potholes Reserve units at PR occurred during the 1980s (R. Friesz and J. Tabor, Washington 
Department of Fish and Wildlife, personal communication), which closely preceded leopard frog declines. We found leopard frogs almost absent from these units. Bullfrogs prey readily on other ranids, including leopard frogs, and consume both larval and newly metamorphosed stages (McAlpine and Dilworth 1989, authors' personal observation). Smith (1977) found that up to $80 \%$ of bullfrog diets consisted of frogs. Bullfrogs also may displace ranid frogs competitively (Kiesecker and Blaustein 1997, Kupferberg 1997) and may be more tolerant of disturbed environments (Kruse and Francis 1977, Hayes and Jennings 1986). Kupferberg (1997) found that yellow-legged frogs (Rana boylii) were less abundant in areas where bullfrogs became well established and documented that presence of bullfrog tadpoles resulted in a $48 \%$ reduction in survivorship of R. boylii tadpoles.

Herbaceous vegetation loaded in models at both spatial scales and was more abundant at occupied sites, suggesting high relative importance of herbaceous vegetation to leopard frogs during summer. We commonly found adult leopard frogs in moist terrestrial areas covered by low emergent and herbaceous vegetation. Adult leopard frogs become highly terrestrial in summer and may travel long distances $(>3$ $\mathrm{km}$ ) from water under appropriate conditions (Breckenridge 1944, Merrell 1977, Knutson et al. 2004). Factors important to adults during summer include prey abundance, herbaceous cover, and moisture (Dole 1965, Merrel 1977, Seburn et al. 1997, Smith 2003). However, we observed that most herbaceous habitat occurred in small patches $(\leq 0.04 \mathrm{ha})$ and was restricted to within 10-20 $\mathrm{m}$ of pond margins, suggesting that this important seasonal habitat component may be a limiting factor for leopard frogs in our system.

During summer, juvenile leopard frogs frequent the margins of more-permanent bodies of water (Merrell 1970), and this behavior may have contributed to our observation that occupied ponds tended to be slightly deeper than unoccupied ones. Also, pond depths were negatively correlated with the likelihood of a pond drying prior to completion of metamorphosis, and this may have contributed to our observation of occupancy at deeper ponds. We observed juveniles most frequently on floating vegetative mats and in terrestrial and aquatic areas containing low emergent vegetation (e.g.,
Eleocharis, Carex, and Scirpus spp.). In a telemetry study of leopard frogs at a natural site in Minnesota, Pember et al. (2002) observed leopard frogs in natural grass, aquatic emergent, and wet meadow vegetation $83 \%$ of the time during summer.

Finally, we advise caution when interpreting the coefficients of our tall emergent vegetation model. We focused surveys primarily on areas of herbaceous and short emergent vegetation because leopard frogs frequented these areas during summer (Dole 1965) and because leopard frogs were seldom found in grassy vegetation a meter or more high (Merrell 1977). Also, in a radiotelemetry study in nearby Idaho, Merriam (2002) observed leopard frogs $87 \%$ of the time in microsites having no overstory vegetation. We therefore spent relatively little time searching in tall emergent vegetation and recognize the possibility that we occasionally may have failed to detect leopard frogs in these areas. For this reason, we advise that any efforts to reduce tall emergent vegetation to favor leopard frogs be closely combined with intensive effects monitoring.

\section{Management Implications}

Our results suggest that removal of nonnative fish and bullfrogs will benefit northern leopard frogs. In California, Rana muscosa population densities increased 40-fold following removal of nonnative fish (Knapp et al. 2007), and the tadpole stage appeared to be the most vulnerable life stage (Vredenburg 2004). Petranka (1983) found densities of Ambystoma texanum larvae 16-fold greater in years when predatory fish were absent from breeding reaches of streams. Adams (1999) found fish to have a greater negative impact on Rana aurora than did bullfrogs. In systems where water levels are artificially managed (such as ours), some leeway exists for water-level manipulation even within irrigation constraints. Fish removal could be accomplished via drawdowns, by pumping isolated ponds dry, or with applications of Rotenone ${ }^{\circledR}$ during late summer or fall, after leopard frog larvae have metamorphosed and when water levels are already at annual lows.

Reducing bullfrog larvae may facilitate leopard frog coexistence (Doubledee et al. 2003), but such reduction should be carefully monitored because survival and growth of bullfrog larvae can be density dependent (Govindarajulu 
2004). Stage-specific population modeling by Govindarajulu et al. (2005) suggests that if efforts are undertaken to remove bullfrog larvae, methods with potential to achieve nearcomplete removal, such as drawdowns and rotenone application, should be used.

At the pond scale, we recommend reducing tall emergent vegetative cover to $\leq 20 \%$ (based on our interquartile-range estimates of occupied sites) of the total cover along the perimeters of ponds. This can be accomplished most efficiently by burning or mechanical removal and, to avoid mortalities, should be done during winter hibernation or early spring when frogs are at aquatic-breeding positions. In place of tall emergent vegetative cover, herbaceous vegetative cover should be encouraged to compose $30 \%-90 \%$ of the vegetation along the perimeters of ponds used as summer habitat (see Fig. 1).

At the 1-km scale, depths of breeding ponds (which may not be the same ponds as oversummering ponds) should be maintained at $\geq 0.5 \mathrm{~m}$ until metamorphosis is completed in mid-July, after which we encourage drawdowns at ponds containing nonnative fish or bullfrog larvae. Patches of herbaceous vegetation exceeding 0.4 ha should be encouraged and could be brought about simultaneously with burning and other actions designed to reduce tall emergent vegetation. Herbaceous patches should be implemented first at ponds known to be used by leopard frogs during summer. Finally, reducing the overall number of ponds containing bullfrogs, carp, and nonnative sport fish will benefit leopard frogs. These management actions should be coupled with continued monitoring at a level sufficient to evaluate their effectiveness for conserving northern leopard frog populations in Washington and elsewhere.

Optimally, the enactment of any of these recommendations should be coupled with a monitoring effort designed to assess whether such a management action achieves predefined response levels for both the direct management targets (e.g. tall emergent vegetation) and leopard frogs (Morrison et al. 2001). Also, the management plan should be cast in an adaptive framework, where monitoring information directs decisions about whether a particular action should be continued, altered, or replaced by another management action (Block et al. 2001).

\section{ACKNOWLEDGMENTS}

We thank the following individuals for help conducting fieldwork: Laura Cooke, Erik Ellis, Steve Goodman, John Heimburg, Scott Leach, Kim Romain-Bondi, and JoAnn Wisniewski. Greg Fitzgerald, Ron Friesz, Marc Hayes, Jeff Korth, Marc Peterson, and Jim Tabor shared information about the study area and provided valuable comments during development of this study and preparation of this paper. Mike Adams, Marc Hayes, Ryan O’Donnell, Matt Vander Haegen, and JoAnn Wisniewski provided valuable editorial comments on an earlier draft of this paper. Funding was provided by a Federal Aid in Restoration of Fish and Wildlife Grant from the U.S. Fish and Wildlife Service.

\section{Literature Cited}

Adama, D.B., K. Lansley, and M.A. Beaucher. 2004. Northern leopard frog (Rana pipiens) recovery: captive rearing and reintroduction in southeast British Columbia, 2003. Report to the Columbia Basin Fish and Wildlife Compensation Program, Nelson, British Columbia, Canada.

Adams, M.J. 1999. Correlated factors in amphibian decline: exotic species and habitat change in western Washington. Journal of Wildlife Management 63:1162-1171.

Alberta Environmental Protection. 1996. The Wildlife Act. Alberta Environmental Protection, Natural Resources Service, Alberta, Canada.

AnOnymous. 2006. Petition to list the western U.S. population of the northern leopard frog as a threatened species under the Endangered Species Act. Available from: http://www.nativeecosystems.org/species /northern-leopard-frog/2006-6-12\%20Final\%20 Leopard\%20Frog\%20Petition.pdf/view

Block, W.M., A.B. Franklin, J.P. Ward, Jr., J.L. Ganey, AND G.C. White. 2001. Design and implementation of monitoring studies to evaluate the success of ecological restoration on wildlife. Restoration Ecology 9:293-303.

Bradford, D.F., F. Tabatabai, and D.M. Graber. 1993. Isolation of remaining populations of the native frog, Rana muscosa, by introduced fishes in Sequoia and Kings Canyon National Parks, California. Conservation Biology 7:882-888.

Breckenridge, W.J. 1944. Reptiles and amphibians of Minnesota. University of Minnesota Press, Minneapolis.

Burnham, K.P., And D.R. Anderson. 2002. Model selection and multimodel inference: a practical informationtheoretic approach. Springer-Verlag, New York.

[COSEWIC] Committee on the Status of Endangered Wildlife in Canada. 2002. Canadian species at risk. May 2002. Government of Canada, Ottawa, Ontario.

Conservation Data Centre. 2001. Provincial Red and Blue Lists. British Columbia Ministry of Water, Land and Air Protection, Victoria, British Columbia, Canada. 
CoRn, P.S. 1994. What we know and what we don't know about amphibian declines in the west. Pages 59-67 in W. Covington and L. DeBano, technical coordinators, Sustainable ecological systems: implementing an ecological approach to land management. General Technical Report RM-247, USDA Forest Service.

Crump, M.L., AND N.J. SCOTT. 1994. Visual encounter surveys. Pages 84-91 in W.R. Heyer, editor, Measuring and monitoring biological diversity: standard methods for amphibians. Smithsonian Institution Press, Washington, DC

DoLE, J.W. 1965. Summer movements of adult leopard frogs, Rana pipiens Schreber, in northern Michigan. Ecology 46:236-255.

1971. Dispersal of recently metamorphosed leopard frogs, Rana pipiens. Copeia 1971:221-228.

Doubledee, R.A., E.B. Muller, and R.M. Nisbet. 2003. Bullfrogs, disturbance regimes, and the persistence of California red-legged frogs. Journal of Wildlife Management 67:424-438.

Govindarajulu, P. 2004. Introduced bullfrogs (Rana catesbeiana) in British Columbia: impacts on native Pacific tree frogs (Hyla regilla) and red-legged frogs (Rana aurora). Doctoral dissertation, University of Victoria, Victoria, British Columbia, Canada.

Govindarajulu, P., R. Altwegg, and B.R. Anholt. 2005. Matrix model investigation of invasive species control: bullfrogs on Vancouver Island. Ecological Applications 15:2161-2170.

Groves, C.R., And C. Peterson. 1992. Distribution and population trends of Idaho amphibians as determined by mail questionnaire. Final Report, Idaho Department of Fish and Game, Boise, ID.

Hayes, M.P., and M.R. Jennings. 1986. Decline of ranid frogs in western North America: are bullfrogs (Rana catesbeiana) responsible? Journal of Herpetology 20: 490-509.

Hecnar, S.J., and R.T. M'Closkey. 1997a. The effects of predatory fish on amphibian species richness and distribution. Biological Conservation 79:123-131.

1997b. Changes in the composition of a ranid frog community following bullfrog extinction. American Midland Naturalist 137:145-150.

HiLl, M.O., R.G.H. Bunce, and M.W. Shaw. 1975. Indicator species analysis, a divisive polythetic method of classification and its application to a survey of native pinewoods in Scotland. Journal of Ecology 63:597-613.

Hine, R.L., B.L. Les, AND B.F. Hellmich. 1981. Leopard frog populations and mortality in Wisconsin, 1974-1976. Technical Bulletin No. 122, Wisconsin Department of Natural Resources, Madison, WI.

Hosmer, D.W., AND S.L. Lemeshow. 1989. Applied logistic regression. John Wiley \& Sons, Inc., New York.

Jongman, R.H.G., C.J.F. Ter Braak, and O.F.R. Van Tongeren. 1995. Data analysis in community and landscape ecology. Cambridge University Press, Cambridge.

Kats, L.B., J.W. Petranka, and A. Sin. 1988. Antipredator defenses and the persistence of amphibian larvae with fishes. Ecology 69:1865-1870.

KENDELL, K. 2002. Survey protocol for the northern leopard frog. Alberta Sustainable Resource Development, Fish and Wildlife Division, Alberta Species at Risk Report No. 43. Edmonton, Alberta, Canada.

. 2003. Status of the northern leopard frog (Rana pipiens) in Alberta: update 2003. Alberta Sustainable
Resource Development, Fish and Wildlife Division, and Alberta Conservation Association, Wildlife Status Report No. 9. Edmonton, Alberta, Canada.

Kiesecker, J.M., and A.N. Blaustein. 1997. Population differences in responses of red-legged frogs (Rana aurora) to introduced bullfrogs. Ecology 78: $1752-1760$.

Knapp, R.A., D.M. Boiano, and T. Vredenburg. 2007. Removal of nonnative fish results in population expansion of a declining amphibian (mountain yellowlegged frog, Rana muscosa). Biological Conservation 135:11-20.

Knutson, M.G., W.B. Richardson, D.M. Reineke, B.R. Gray, J.R. Parmelee, and S.E. Weick. 2004. Agricultural ponds support amphibian populations. Ecological Applications 14:669-684.

Koch, E.D., G. Wood, C.R. Peterson, and P.S. Corn [EDITORS]. 1997. A summary of the conference on declining and sensitive amphibians in the Rocky Mountains and Pacific Northwest. Idaho Herpetological Society and U.S. Fish and Wildlife Service, Snake River Basin Office Report, Boise, ID.

Kruse, K.C., AND M.G. Francis. 1977. A predation deterrent in larvae of the bullfrog, Rana catesbeiana. Transactions of the American Fisheries Society 106: 248-252.

KupferberG, J.S. 1997. Bullfrog (Rana catesbeiana) invasion of a California river: the role of larval competition. Ecology 78:1736-1751.

Laufer, G., A. Canavero, D. Núñez, and R. Maneyro. 2007. Bullfrog (Lithobates catesbeianus) invasion in Uruguay. Biological Invasions, SpringerLink, 11 October 2007. Available from: http://www.springerlink.com/content/t20555442168v526/.

Leonard, W.P., K.R. McAllister, and R.C. Friesz. 1999. Survey and assessment of northern leopard frog (Rana pipiens) populations in Washington State. Northwestern Naturalist 80:51-60.

Merriam, J.C. 2002. Movements and habitat selection in northern leopard frogs (Rana pipiens) in southeastern Idaho. Doctoral dissertation, Idaho State University, Moscow.

Morrison, M.L., W.M. Block, M.D. StRickland, AND W.L. KendaLL. 2001. Wildlife study design. Springer, New York.

McAllister, K.R., W.P. LeOnard, D.W. Hays, and R.C. Friesz. 1999. Washington State status report for the northern leopard frog. Washington Department of Fish and Wildlife, Wildlife Management Program, Olympia, WA.

McAlpine, D.F., And T.G. DilworTh. 1989. Microhabitat and prey size among three species of Rana (Anura: Ranidae) sympatric in eastern Canada. Canadian Journal of Zoology 67:2242-2252.

Merrell, D.J. 1970. Migration and gene dispersal in Rana pipiens. American Zoologist 10:47-52.

1977. Life history of the leopard frog, Rana pipiens, in Minnesota. University of Minnesota Bell Museum of Natural History Occupational Paper No. 15. Minneapolis, MN.

Monello, R.J., AND R.G. Wright. 1999. Amphibian habitat preferences among artificial ponds in the Palouse region of northern Idaho. Journal of Herpetology 33:298-303.

Olson, D.H., W.P. LeONARD, AND R.B. BurY. 1997. Sampling amphibians in lentic habitats. Society for Northwestern Vertebrate Biology, Olympia, WA. 
PANIK, H.R., AND S. BaRRETT. 1994. Distribution of amphibians and reptiles along the Truckee River system. Northwest Science 68:197-204.

Pember, B.C., B.C. Knights, M.G. Knutson, and S.E. WEICK. 2002. Effects of agricultural and urban land use on movement and habitat selection by northern leopard frogs (Rana pipiens). Report submitted to the Legislative Commission on Minnesota Resources, St. Paul. U.S. Geological Survey, Upper Midwest Environmental Sciences Center, La Crosse, WI. Available from: http://www.umesc.usgs.gov/terrestrial /amphibians/mknutson_5003869.html

Petranka, J.W. 1983. Fish predation: a factor affecting the spatial distribution of a stream-breeding salamander. Copeia 1983:624-628.

Seburn, C.N.L., D.C. Seburn, and C.A. Paszkowski. 1997. Northern leopard frog (Rana pipiens) dispersal in relation to habitat. Herpetological Conservation 1:64-72.

Simmons, H.M. 2002. A field study of the northern leopard frog (Rana pipiens) in the Potholes Reservoir area, Washington. Masters thesis, Central Washington University, Ellensburg, WA.

SKELlY, D.K. 1996. Pond drying, predators, and the distribution of Pseudacris tadpoles. Copeia 1996:599-605.

Sмith, A.K. 1977. Attraction of bullfrogs (Amphibia, Anura, Ranidae) to distress calls of immature frogs. Journal of Herpetology 11:234-235.

SMith, B.E. 2003. Conservation assessment for the northern leopard frog in the Black Hills National Forest, South Dakota and Wyoming. USDA Forest Service, Black Hills National Forest, Custer, SD. Available from: http://www.fs.fed.us/r2/blackhills/projects /planning/assessments/leopard_frog.pdf

StebBIns, R.C. 2003. Field guide to western amphibians and reptiles. 3rd edition. Houghton-Mifflin, New York.
ST. John, A.D. 1985. The herpetology of the Owyhee River drainage, Malheur County, Oregon. Technical Report No. 85-5-03, Nongame Wildlife Program, Oregon Department of Fish and Wildlife, Portland, OR.

SYSTAT 2004. SYSTAT software. SPSS, Inc., Chicago, IL.

[USDI-BOR] UNITED STATES DEPARTMENT OF INTERIOR, Bureau of Reclamation. 2002. Potholes Reservoir Resource Management Plan, Grant County, WA. Upper Columbia Area Office, Ephrata Field Office, Ephrata, WA.

VRedenburg, V.T. 2004. Reversing introduced species effects: experimental removal of introduced fish leads to rapid recovery of a declining frog. Proceedings of the National Academy of Science 101:7646-7650. Available from: http://www.pnas.org_cgi_doi_10.1073 pnas.0402321101

Washington Department of Fish and WildLife. 2005. WDFW Wildlife Heritage Points Database [updated and cited December 2005; R. Deol, data manager]. Northern leopard frog occurrences in Grant County, Washington. Washington Department of Fish and Wildlife, Olympia.

Washington Department of Fish and Wildlife ComMISSION. 2000. Priority habitats and species list. Olympia, WA. Available from: http://wdfw.wa.gov/hab /phsdef.htm

Werner, E.E., And M.A. MCPeEk. 1994. Direct and indirect effects of predators on two anuran species along an environmental gradient. Ecology 75: 1368-1382.

Received 30 September 2008 Accepted 10 June 2009 